Original Research

\title{
Developing a Sediment Rating Curve Model Using the Curve Slope
}

\author{
Hamed Benisi Ghadim*, Meysam Salarijazi², Iman Ahmadianfar ${ }^{3}$, \\ Mohammad Heydari ${ }^{4}$, Ting Zhang ${ }^{5}$
}

${ }^{1}$ Department of Water Resources and Harbor Engineering, College of Civil Engineering, Fuzhou University, Fuzhou, China.

${ }^{2}$ Department of Water Engineering, Gorgan University of Agricultural Sciences and Natural Resources, Gorgan, Iran

${ }^{3}$ Department of Civil Engineering, Behbahan Khatam Alanbia University of Technology, Behbahan, Iran

${ }^{4}$ University of Malaya, Kuala Lumpur, Malaysia

${ }^{5}$ Department of Water Resources and Harbor Engineering, College of Civil Engineering, Fuzhou University, Fuzhou, China

Received: 14 September 2018

Accepted: 30 January 2019

\begin{abstract}
There are different ways to estimate suspended sediment load of a river. The conventional sediment rating curve model has been used widely due to its simplicity and required parameters. The most important limitation of the conventional SRC model is its relatively low precision and underestimation of the suspended sediment load in most studies. However, in this study, the concept of SRC model segmentation is introduced based on the curve slope under the title of developed SRC-S model. The most important feature is the simplicity of the presented application. To compare the conventional SRC and the developed SRC-S models, data from two hydrometry stations in northern Iran were selected. Graphical study of the models shows that the developed SRC-S model enjoys more fitting precision in comparison with the conventional SRC model, and also has improved underestimation error of suspended sediment load in higher rates of river flow discharge. Six numerical criteria for model accuracy (Nash-Sutcliffe, root-mean-square error, and mean absolute error, difference ratio, efficiency ratio improved and index of agreement) are used for quantitative comparison of the results of conventional and developed models. Accordingly, we found that the mentioned criteria have improved significantly compared to the conventional model.
\end{abstract}

Keywords: sediment rating curve, estimation, curve slope, suspended sediment load

*e-mail: hbghadim@yahoo.com, haslinbeni@gmail.com 


\section{Introduction}

Nowadays, there is a desire to understand how sediment transport occurs in rivers in aspects of quality and quantity. As all of this information is subsequently used in studying erosion rate and pattern, evaluating erosive material from lands surface toward the downstream of the basin, examining water resource pollution - especially non-point source (NPS) pollution, sediment balance, and drainage basin management [1-2]. Unfortunately, many human activities intensify erosion processes, sediment transport, and sedimentation. For example, by removing plants, land erosion will accelerate and a high volume of sediment transport will flow into rivers [3-5]. In addition, some rivers carry higher sediments in comparison with the world's rivers, due to weather conditions, hydrological and geological situations, and pressure on basin lands, which leads to a lot of damage [6-8]. Stream sediments are transferred in two patterns. First, the sediment is immersed in and moved with water, which is called suspended sediment and its amount crossing a section of the river per time unit is called the suspended load. Second, the sediments are in the forms of slip, rolling or jumping motions which are called bed load [9]. The suspended load measurement method based on the measurement of suspended sediment concentration and flow rate is a stable and reliable method for estimating annual sediment load, but requires continuous measurement that is usually allowed only for major permanent rivers [10-12]. Because many catchments do not include continuous daily measurements of sediment in most countries, it would be necessary to use experimental and statistical models for estimating suspended sediment load in such rivers [13-14]. So far, various methods have been suggested for estimating suspended sediment load, the results of which show significant differences in most cases [15]. One of the most important applications of the methods for estimating suspended sediment load of rivers is to apply them for estimating annual sediment load of the river sediment. It is clear that differences in methods of estimating the suspended sediment quantity can lead to quite different estimations of annual longterm sediment load of a given basin [16-17]. Methods for estimating suspending sediment load of rivers often fallen into the two categories of "hydrological methods" and "hydraulic methods", the former being considered as more suitable in practice due to its ease of use [18]. The Conventional model of Sediment Rating Curve (SRC) is a simple well-known hydrological method for estimating suspended sediment load of rivers, which takes advantage of a power regression equation between suspended sediment load (dependent variable) and river flow discharge (independent variable) [19]. The other form of this model is to apply linear regression between log transformation of suspended sediment load data and river flow discharge, which statistically equals the initial form [20]. Due to its ease of use and requiring just a river flow discharge for estimating suspended sediment load, the conventional SRC model has been extensively used in practice [21]. In his investigations along the Mississippi River, Horowitz (2003) [22] found that by applying linear and non-linear regression it has become clear that the longer the data collection period and the fewer intervals between measurements, the less will be the overestimation and underestimation values. Achite and Ouillon (2007) [23] showed that, firstly, the anticipated values using repression equations were $20 \%$ to $25 \%$ more than real values, and secondly, based on the available time series, achieving more accurate estimation requires long-term periods, and they suggested that climate change also needs to be considered. RodríguezBlanco et al. (2010) [24] examined the time changes of suspended sediment transport in northwest Spain and used suspended sediment and flow discharge data collected over 3 years (2004-2007) in different seasonal, monthly and yearly time scales. The results of their research suggest that there is a significant relationship between occurring changes in the amount of suspended sediment generation with the number and intensity of the runoff events. They also emphasized the role that sediment has in transporting nutrients and pollutants to coastal areas of the study region. Various studies have been conducted on the conventional SRC model as an all-purpose model. In a few cases it has been mentioned that it can lead to overestimation of suspended sediment load [25], but in many other cases this model had resulted in underestimating suspended sediment load [26-31].

Several types of research have been done on the applicability of corrective coefficients for resolving the underestimation problem in the conventional SRC model, which deals with one coefficient for the whole conventional SRC model [28, 32-33]. A non-parametric or smearing estimator was first applied by Duan (1983) [34] in order to improve SRC estimation. This method is used for solving SRC limitation by [35-36, 37]. Ferguson (1986) [32] used a quasi-maximum likelihood estimator (QMLE) to correct the shortcomings of the basic SRC method. This improvement is illustrated by different researchers in sediment load studies [38-40]. Cohnet al. (1989) [41] suggested the MVUE method to overcome backlog-transformation bias as a main problem in conventional SCR application. An important part of research on the estimation of SRCs is focused on improving its efficiency. In this manner, Kao et al. (2005) [33] proposed a beta coefficient method. The mentioned studies emphasized correction of conventional SRC considering a corrected SRC curve fitted among recorded data, but it seems the division of SRC curve to two segmented curves can lead to correction of conventional SRC too. The purpose of this study is to improve the conventional SRC model based on the applicability of the slope curve method (SCM), which is a mathematical method that was first used in water and environment resources issues for estimating environmental flows [42-43]. In this technique, curve slope changes are considered against flow discharge, 
and at the point where curve slope equals 1 , the diagram is divided into two sections. This method is based on the assumption that the curve slope values greater and smaller than one is, in fact suggesting two kinds of dependent variable behaviors against an independent variable, and for this reason this technique is used as a concept to divide the diagram into two separate diagrams. Seemingly, this technique has not been used for suspended sediment load calculations of rivers; therefore, we have described it precisely in this study and the result of its application is presented as a developed model of sediment rating curve based on SRC-S curve slope.

\section{Materials and Methods}

\section{Study Area and Used Data}

The Gharehsou basin with an area of approximately $1762 \mathrm{~km}^{2}$ and geographic coordinates of $36^{\circ} 37^{\prime}$ to $37^{\circ} 00^{\prime} \mathrm{N}$ latitude and $54^{\circ} 02^{\prime}$ to $54^{\circ} 44^{\prime} \mathrm{E}$ longitude with special topography is located in northern Iran in Golestan Province. The basin is limited from the north and east to the Gorganrood basin, from the south and west to the Haraz-Neka basin and from the northwest to Gorgan Gulf. The main branch of the Gharehsou River, which is the main drain of the basin, is depleted to Gorgan Gulf and runs from east to west, but its branches are often in the north-to-south direction. The origin of most of the branches of the Gharehsou River is Alborz Mountain. The Kurdkuy, Shastkola,
Garmabdasht anz Ziarat are the most important of these branches. The average elevation of the basin is $624 \mathrm{~m}$ above the free seawater level, which is at least $-26 \mathrm{~m}$ on the Gorgan Gulf coast, and at most $3300 \mathrm{~m}$ in the southern highlands of the basin. The northern areas of the basin are in the form of a plain and its southern area is mountainous fields. In general, there are four types of land use in the study area: forest, pasture, agriculture and residential. The largest area of the basin is allocated to agriculture and the lowest is residential. Agricultural lands are often dispersed in parts of the basin that are plain, while forest areas are mostly located in the middle part of the basin. The pasture lands are concentrated in the mountainous areas of the southern basin as well as parts of the northern basin. The average annual rainfall in Gharehsou basin is about $720 \mathrm{~mm}$, which has the highest and lowest rainfall from November to March and June to August respectively. The Gharehsou River's discharge is increasing from October, reaching its highest values in April, and then the river's discharge decreases monthly and reaches its lowest values in August.

The comparative study of the conventional SRC model and the developed SRC-S model requires the use of recorded real data. The present study uses the water discharge data of the river flow and suspended sediment load of two hydrometry stations in the Gharehsou River basin. Fig. 1 shows the location of the Gharehsou basin in the Iranian map and the study stations. The characteristics of the used data in the study are presented in Table 1.

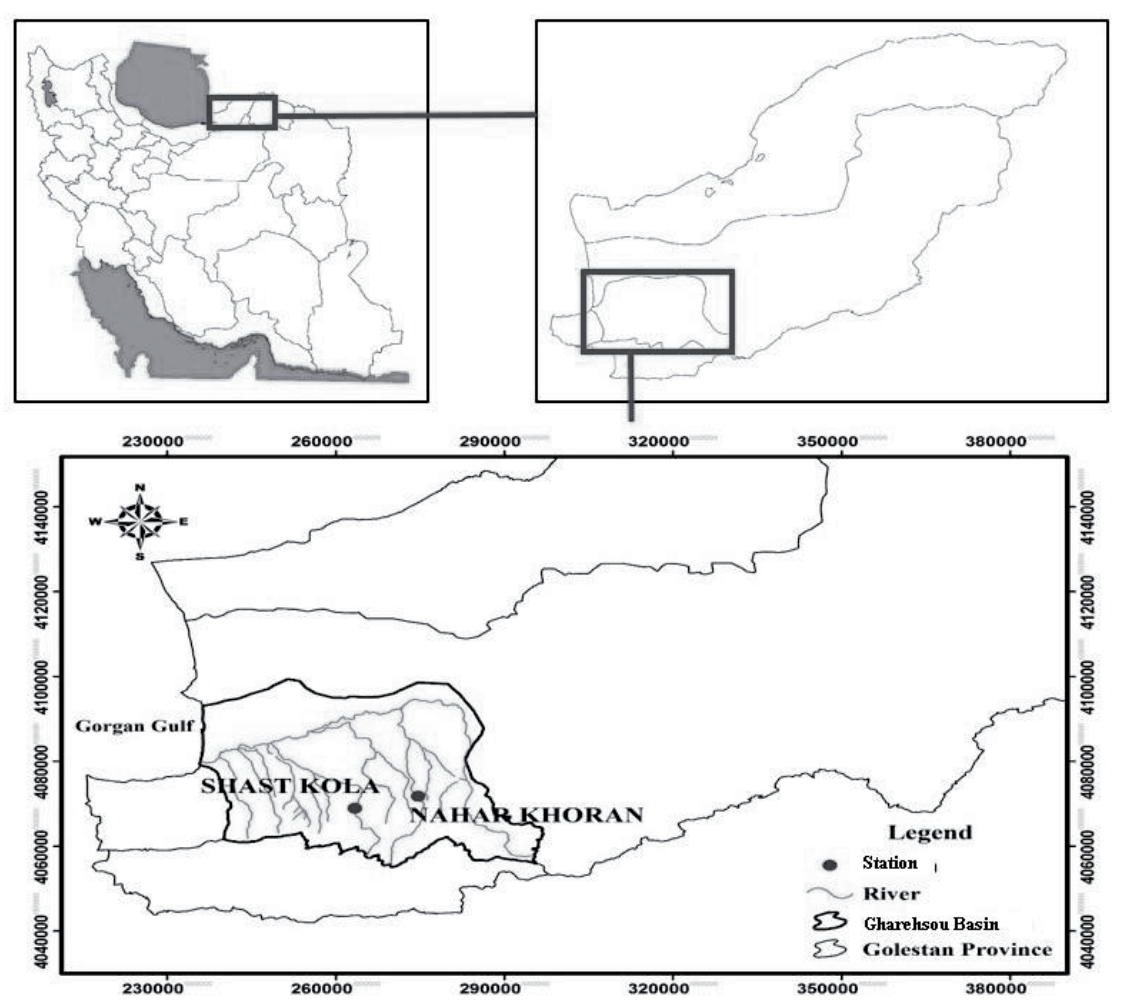

Fig. 1. Geographic locations of the study area and its hydrometry stations. 
Table 1. Statistical characteristics of the river water discharge data and suspended sediment load.

\begin{tabular}{|c|c|c|c|c|c|c|}
\hline Series & Variable (Unit) & Recorded Data & Average & Max & Min & SD \\
\hline \multirow{2}{*}{ Naharkhoran } & Discharge (m/s) & 329 & 0.32 & 4.89 & 0.01 & 0.43 \\
\cline { 2 - 7 } & Suspended Sediment Load (Ton/Day) & 329 & 17.31 & 2491.13 & 0.00012 & 170.65 \\
\hline \multirow{2}{*}{ Shastkola } & Discharge (m/s) & 113 & 0.38 & 4.43 & 0.04 & 0.44 \\
\cline { 2 - 7 } & Suspended Sediment Load (Ton/Day) & 113 & 16.35 & 1787.29 & 0.001 & 168.10 \\
\hline
\end{tabular}

\section{Conventional SRC Model}

The regression method is often used to determine a relationship between suspended sediment load and river water discharge. Typically, the linear regression on logtransformed data of the two variables is used as follows:

$$
\log (C)=b \log (Q)+\log (a)
$$

...where "a" and " $b$ " are curved coefficients. In this equation, $b$ is the line slope of the log-transformed data of water discharge and also the value of suspended sediment load, and log (a) is equal with y-intercept. The above equation is often used in power form [19].

$$
C=a Q^{b}
$$

As explained previously, most of the studies suggest that the use of the conventional SRC model has a significant error, especially in underestimating the suspended sediment load.
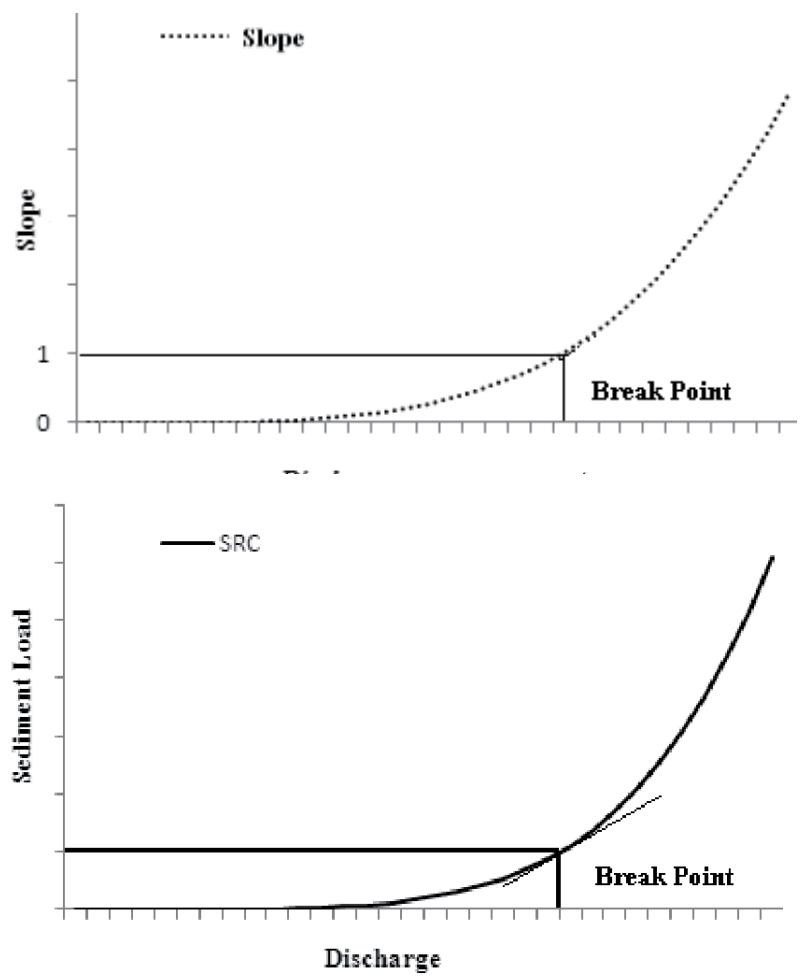

Fig. 2. Schematic view of break-point determination in the developed SRC-S model using the slope of the curve method.

\section{The Developed SRC-S Model}

The break-point in the curve is determined by revealing the power curve equation that is done using the slope of the curve method, in which the critical point is a point where the slope of the curve is fitted to the following equation [42-43]. The expressed concept is shown in Fig. 2.

$$
\frac{d C}{d Q}=1
$$

Accordingly, the power equation takes the following form so that we can determine the break-point. Next, the data are divided into two parts according to break-point and on each part; a separate curve fitting is given.

$$
\text { b.a. } Q^{b-1}=1
$$

\section{Model Precision Criteria}

The evaluation criteria of the model precision can be classified into two categories. The first is the graphic criterion that addresses a visual review of the precision of fitting. It should be noted that it is not a quantitative criterion, but it has a qualitative form and it is explained as a descriptive form. The second category is the numerical criteria that leads to calculating the statistic defined criteria that provide the possibility to compare the results in terms of quality from different dimensions. The various numerical criteria used in this research are described below.

\section{Root Mean Square Error}

$$
R M S E=\sqrt{\frac{\sum_{i=1}^{n}\left(C_{o_{i}}-C_{e_{i}}\right)^{2}}{n}}
$$

In the above and other equations, is the value of observed suspended sediment load, is the estimated suspended sediment load and $\mathrm{n}$ is the number of samples. This criterion shows the observed and estimated distribution means of the difference of values. But this index cannot provide the information about over-estimation or underestimation of a method [44]. The nearer the values of this index to zero, the 
smaller the average difference between observed and estimated values, and the used model will have less error [45].

$$
\begin{aligned}
& \text { Mean Absolute Error } \\
& M A E=\frac{\sum_{i=1}^{n}\left|C_{o_{i}}-C_{e_{i}}\right|}{n}
\end{aligned}
$$

The mean absolute error criterion shows the difference between estimated and observed values [46]. Obviously, the MAE value of criterion has been always positive, and ideally this criterion is equal to zero [47].

$$
\begin{gathered}
\text { Difference Ratio } \\
\qquad D R=\frac{C_{e_{m}}}{C_{o_{m}}}
\end{gathered}
$$

In the above and other equations, is the mean value of observed suspended sediment load and is the mean value of estimated suspended sediment load. The criterion is obtained from the ratio of the estimated mean values to the observed mean values, and the closer the value of this index to one, the higher the model precision [48]. Specifically, if the model on average has an over-estimation, the value of the criterion will be more than one and if the model on average has an underestimation, the value of the criterion will be less than one.

$$
\begin{aligned}
& \text { Efficiency Ratio Improved } \\
& E R I=1-\left(\frac{\sum_{i=1}^{n}\left|C_{o_{i}}-C_{e_{i}}\right|}{\sum_{i=1}^{n}\left|C_{o_{i}}-C_{o_{m}}\right|}\right)
\end{aligned}
$$

This criterion ranges between 1 and- $\infty$ [49]. If the ERI criterion value is equal to 1 , therefore, the further the value of this index goes from 1, the less the precision of the estimated values and the efficiency of the model.

$$
\begin{gathered}
\text { Index of Agreement } \\
I A=1-\frac{\sum_{i=1}^{n}\left|C_{e_{i}}-C_{o_{i}}\right|}{\sum_{i=1}^{n}\left(\left|C_{e_{i}}-C_{o_{m}}\right|+\left|C_{o_{i}}-C_{o_{m}}\right|\right)}
\end{gathered}
$$

The Index of Agreement (IA) is widely used to examine the model's efficiency [50]. The index represents the rate of conformity between the estimated data and observed data. Whatever value of the index is closer to 1 , the rate of conformity increases more [51].

\section{Nash-Sutcliffe Criterion}

$$
N S=1-\left(\frac{\sum_{i=1}^{n}\left(C_{o_{i}}-C_{e_{i}}\right)^{2}}{\sum_{i=1}^{n}\left(C_{o_{i}}-C_{o_{m}}\right)^{2}}\right)
$$

Nash-Sutcliffe criterion is one of the error estimation criteria that is widely used in modeling water and hydrology resources [52]. This index ranges from 1 to $-\infty$; the closer the index value is to 1 , the more efficient the model [52].

\section{Results and Discussion}

A Conventional SRC model is, in fact, fitting a power regression model to the plotted data of suspended sediment load against the river flow discharge. Fig. 3 displays the conventional SRC models fitted to the data in two data series. As has been shown in the figure, in the low levels of river discharge flow, this model has a good fit to the data of suspended load, but by increasing the rate of discharge, the error of the model increases. Numerical criteria precision of the conventional SRC models for used series of data in this study are presented in Table 2.
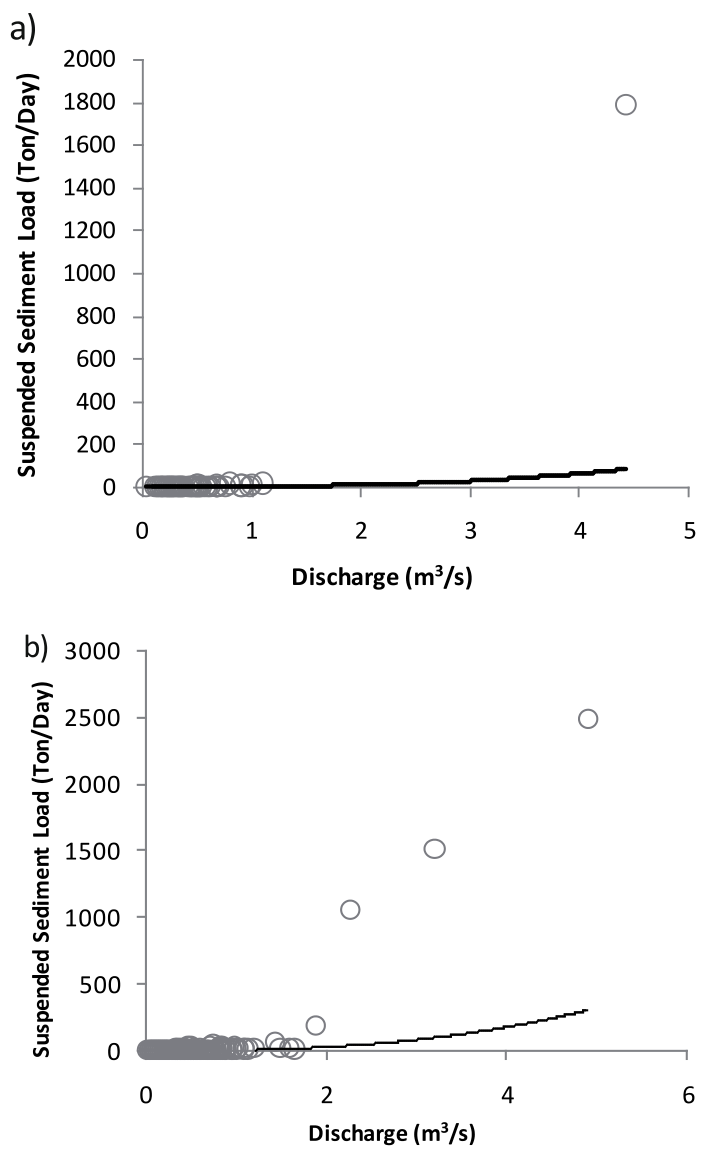

Fig. 3. Conventional SRC model, Shastkola data series a) and Naharkhoran data series b). 

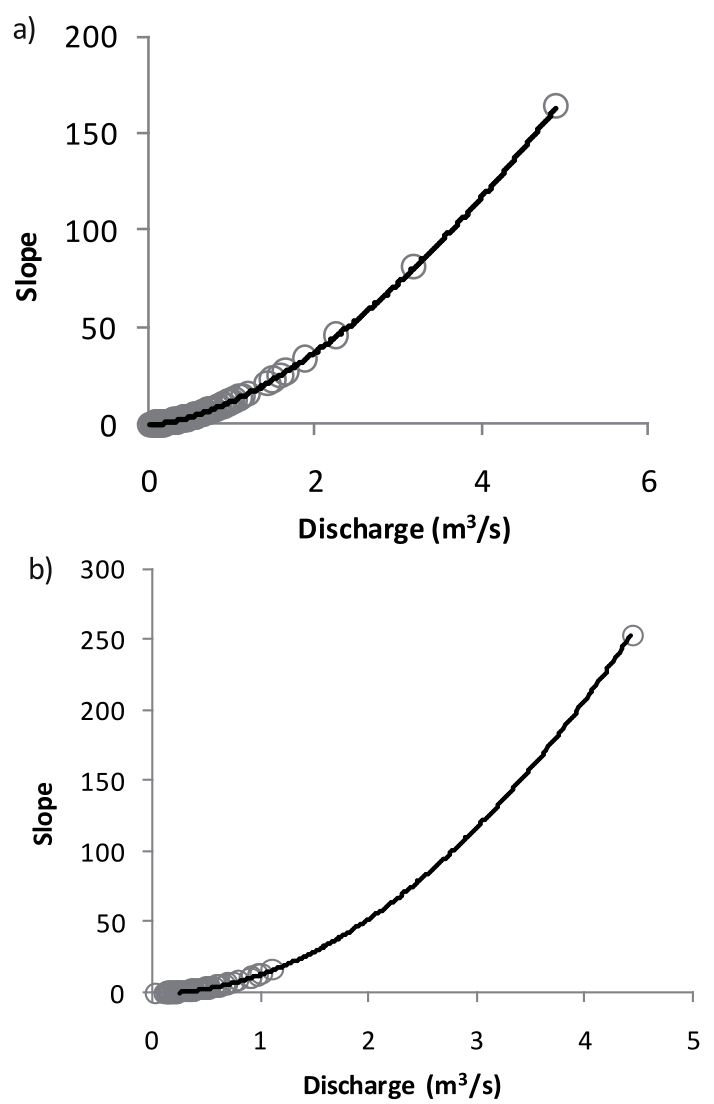

Fig. 4. Discharge-Slope diagram for Naharkhoran a) and Shastkola b) data series.

As previously mentioned, in the developed SRC-S model the slope of the conventional SRC model diagram flow of river discharge should be plotted for each of the used data series, the point equal to one as the point of failure is selected and then the data is divided into two parts: before and after the point of failure. Fig. 4 presents the mentioned graphs for the SRC-S model. Checking these two graphs shows that the points of failure in the data set in Naharkhoran and Shastkola are 0.22 and $0.27 \mathrm{~m}^{3}$ per second, respectively.

Based on the determined breakpoints in each data series, the studied series for Naharkhoran and Shastkola was divided into parts of before and after the point of failure as presented in Figs 5 and 6. Surveying the figures shows that in both studied series, the second part of data has far less difference between the estimated values by the model developed by SRC-S and observed values than the corresponding values of the conventional SRC model.

Values of fitting precision criteria of the developed SRC-S model compared to the conventional SRC model are presented in Table 2. Investigating the NS criteria indicates that the value of this criterion in the conventional SRC model in two series (Naharkhoran and Shastkola) are 0.18 and 0.08 , and in the developed model these values are improved by 0.75 and 0.77 , respectively, which reflects a significant improvement in the precision of the developed model.
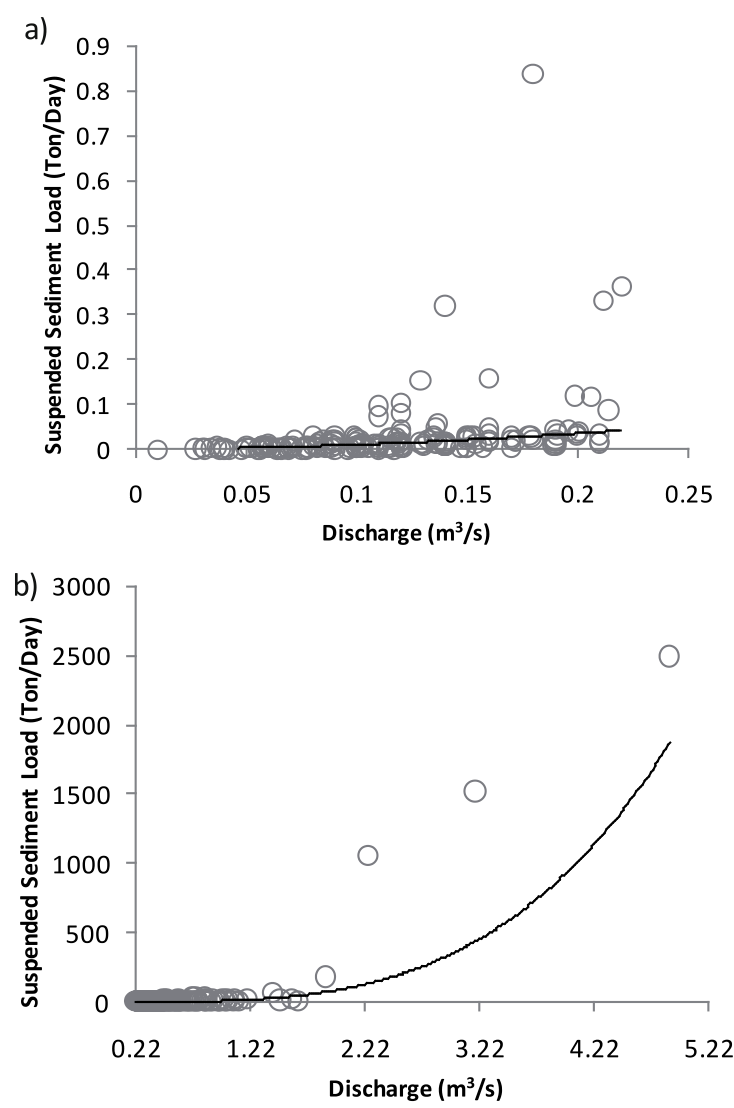

Fig. 5. Developed SRC-S model curves - the first part a) and the second part b) for the Naharkhoran data series.
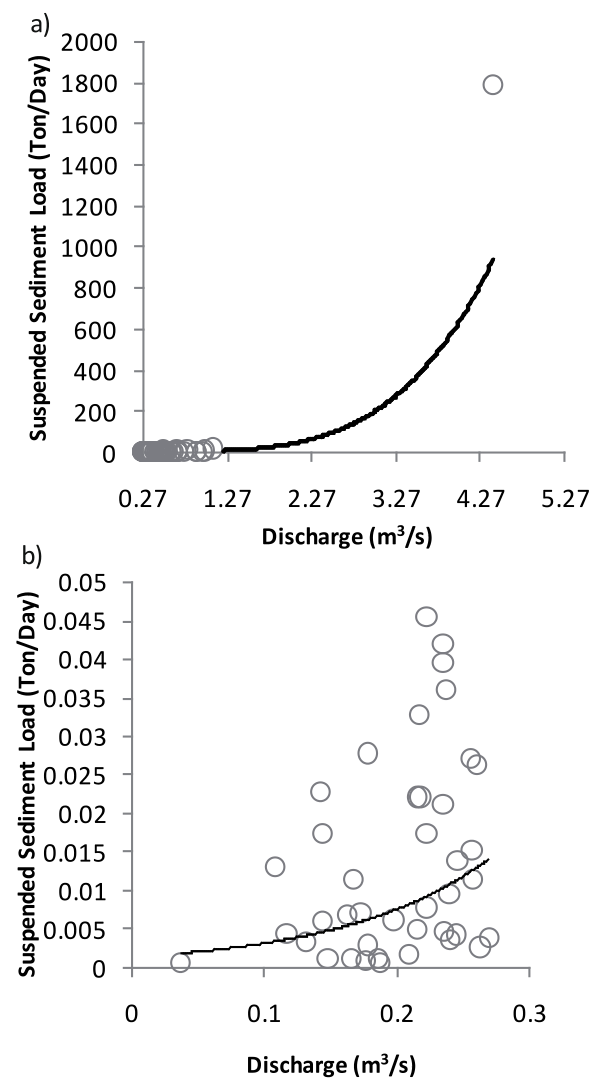

Fig. 6. Developed SRC-S model curves - the first part a) and the second part b) for the Shastkola data series. 
Table 2. Precision criteria of the examined models.

\begin{tabular}{|c|c|c|c|c|c|c|c|}
\hline Series & & NS & RMSE & MAE & DR & ERI & IA \\
\hline \multirow{4}{*}{ Naharkhoran } & SRC & 0.18 & 154.55 & 15.56 & 0.12 & 0.51 & 0.69 \\
\cline { 2 - 9 } & SRC-S & 0.75 & 85.62 & 9.52 & 0.50 & 0.70 & 0.83 \\
\cline { 2 - 9 } & Changes & 0.57 & -68.93 & -6.04 & 0.39 & 0.19 & 0.14 \\
\hline \multirow{3}{*}{ Shastkola } & SRC & 0.08 & 160.58 & 15.60 & 0.05 & 0.50 & 0.68 \\
\cline { 2 - 9 } & SRC-S & 0.77 & 79.47 & 7.94 & 0.52 & 0.75 & 0.86 \\
\cline { 2 - 9 } & Changes & 0.69 & -81.11 & -7.66 & 0.47 & 0.24 & 0.18 \\
\hline
\end{tabular}

RMSE criteria for Naharkhoran and Shastkola series is reached from 154.55 and 168.57 to 85.62 and 79.47, respectively, which indicates that this precision criterion is improved almost twice. MAE criterion for the mentioned series (Naharkhoran and Shastkola series) improved from 15.56 and 15.60 to 9.52 and 7.94, which represents the similar pattern of RMSE criterion changes.

DR criteria for two series (Naharkhoran and Shastkola) in the Conventional SRC model were 0.12 and 0.05 , respectively, which reflects the high intensity of the underestimated problem by the model in this study. However, in the model developed by SRC-S, these criteria increased $50 \%$ and $52 \%$, respectively, which indicates a lower error of underestimation in the developed model than the conventional SRC models.

ERI criteria for the conventional model in the data series Naharkhoran and Shastkola were 0.51 and 0.50 , and this value is improved to 0.70 and 0.75 in the developed model and also IA criteria for the conventional model are improved from 0.69 and 0.68 to 0.83 and 0.86 , respectively, which in fact proves better results in the developed model compared with the conventional models.

\section{Conclusions}

The Conventional SRC model is widely used by engineers and researchers due to its ease of use. Therefore, methods that can improve the precision of the modeling of suspended sediment load are important. In this research, the slope of the curve method is used for segmentation of the conventional SRC model and the results of the developed SRC-S were compared with conventional models.

Our analysis of results is based on data of Naharkhoran and Shastkola hydrometry stations in northern Iran, which lead to the following conclusions:

A) The conventional SRC model has an obvious error in estimating the suspended sediment load and this error is greater at higher discharge rates.

B) Based on the numerical criteria of fitting precision, the precision of the conventional SRC model is not suitable and the rate of underestimation error is quite remarkable.

C) The conventional SRC model is almost the same in both investigated data sets.

D) The developed SRC-S model converts the conventional SRC model into two pieces at lower discharge rates.

E) The precision of developed models (SRC-S) in suspended sediment load estimation in high values of discharge is significantly better than the conventional SRC models.

F) Based on all fitting precision criteria, the developed SRC-S model has significantly improved precision compared to the conventional SRC model. Also, the underestimation error in the developed SRC-S model clearly shows improvement in comparison with the conventional SRC model.

G) The precision of modeling by the SRC model in Naharkhoran was better than Shastkola, while in the developed SRC-S model, the precision of modeling in Shastkola was better than Naharkhoran in general. According to the results of this study, we recommend that in a more comprehensive study a comparison is made between the conventional SRC model and the developed SRC-S model using a larger number of recorded data series from various basins with land use diversification, vegetation, climate and hydrological conditions.

\section{Acknowledgements}

The authors would like to thank the Iran Meteorological Organization and the National Natural Science Foundation of China (grant No. 51679042) for the financial support to conduct the research work in these premises and for technical assistance. The authors would also like to emphasize that all the data used in this research were obtained by the authors through monitoring stations and field measurements.

\section{Conflict of Interest}

The authors declare no conflict of interest. 


\section{References}

1. DUVERT C., GRATIOT N., EVRARD O., NAVRATIL O., NÉMERY J., PRAT C., ESTEVES M. Drivers of erosion and suspended sediment transport in three headwater catchments of the Mexican Central Highlands. Geomorphology, 123 (3), 243, 2010.

2. REN M. E. Sediment discharge of the Yellow River, China: Past, present and future - A synthesis. Acta Oceanologica Sinica, 34 (2), 1, 2015.

3. MUÑOZ-SALINAS E., CASTILlO M. Streamflow and sediment load assessment from 1950 to 2006 in the Usumacinta and Grijalva Rivers (Southern Mexico) and the influence of ENSO. Catena, 127, 270, 2015.

4. REUSSER L., BIERMAN P., ROOD D. Quantifying human impacts on rates of erosion and sediment transport at a landscape scale. Geology, 43 (2), 171-174, 2015.

5. RODRÍGUEZ-BLANCO M.L., ARIAS R., TABOADACASTRO M.M., NUNES J.P., KEIZER J.J., TABOADACASTRO M.T. Potential Impact of Climate Change on Suspended Sediment Yield in NW Spain: A Case Study on the Corbeira Catchment. Water, 8 (10), 4442016.

6. BUSSI G., DADSON S.J., PRUDHOMME C., WHITEHEAD P.G. Modelling the future impacts of climate and land-use change on suspended sediment transport in the River Thames (UK). Journal of hydrology, 542, 357, 2016

7. HEYDARI M., OTHMAN F., NOORI M. A review of the Environmental Impact of Large Dams in Iran. International Journal of Advancements Civil Structural and Environmental Engineering, IJACSE, 1 (1), 4, 2013.

8. KAMARINAS I., JULIAN J.P., HUGHES A.O., OWSLEY B.C., DE BEURS K.M. Nonlinear changes in land cover and sediment runoff in a New Zealand catchment dominated by plantation forestry and livestock grazing. Water, 8 (10), 436, 2016

9. NAQSHBAND S., RIBBERINK J.S., HULSCHER S.J. Using both free surface effect and sediment transport mode parameters in defining the morphology of river dunes and their evolution to upper stage plane beds. Journal of Hydraulic Engineering, 140 (6), 06014010 , 2014.

10. GUZMAN C., TILAHUN S., ZEGEYE A., STEENHUIS T. Suspended sediment concentration-discharge relationships in the (sub-) humid Ethiopian highlands. Hydrology and Earth System Sciences, 17 (3), 1067, 2013.

11. HIGGINS A., RESTREPO J.C., ORTIZ J.C., PIERINI J., OTERO L. Suspended sediment transport in the Magdalena River (Colombia, South America): Hydrologic regime, rating parameters and effective discharge variability. International Journal of Sediment Research, 31 (1), 25, 2016.

12. ROY N., SINHA R. Effective discharge for suspended sediment transport of the Ganga River and its geomorphic implication. Geomorphology, 227, 18, 2014.

13. MOFTAKHARI H., JAY D.A., TALKE S.A., SCHOELLHAMER D.H. Estimation of historic flows and sediment loads to San Francisco Bay, 1849-2011. Journal of hydrology, 529, 1247, 2015.

14. SHIAU J.-T., CHEN T.-J. Quantile regression-based probabilistic estimation scheme for daily and annual suspended sediment loads. Water Resources Management, 29 (8), 2805, 2015.

15. ZHANG W., WEI X., JINHAI Z., YULIANG Z., ZHANG Y. Estimating suspended sediment loads in the Pearl River
Delta region using sediment rating curves. Continental Shelf Research, 38, 35, 2012.

16. HU B., WANG H., YANG Z., SUN X. Temporal and spatial variations of sediment rating curves in the Changjiang (Yangtze River) basin and their implications. Quaternary International, 230 (1), 34, 2011.

17. WANG J.J., LU X., KUMMU M. Sediment load estimates and variations in the Lower Mekong River. River Research and Applications, 27 (1), 33-46, 2011.

18. SALARIJAZI M., ABDOLHOSSEINI M., GHORBANI K., ESLAMIAN S. Evaluation of quasi-maximum likelihood and smearing estimator to improve sediment rating curve estimation. International Journal of Hydrology Science and Technology, 6 (4), 359, 2016.

19. DANG T.H., COYNEL A., ORANGE D., BLANC G., ETCHEBER H., LE L.A. Long-term monitoring (1960-2008) of the river-sediment transport in the Red River Watershed (Vietnam): Temporal variability and dam-reservoir impact. Science of the Total Environment, 408 (20), 4654, 2010.

20. KAO S.-J., LEE T.-Y., MILLIMAN J.D. Calculating highly fluctuated suspended sediment fluxes from mountainous rivers in Taiwan. Terrestrial Atmospheric and Oceanic Sciences, 16 (3), 653, 2005.

21. SYVITSKI J.P., MOREHEAD M.D., BAHR D.B., MULDER T. Estimating fluvial sediment transport: the rating parameters. Water resources research, 36 (9), 2747, 2000.

22. HOROWITZ A.J. An evaluation of sediment rating curves for estimating suspended sediment concentrations for subsequent flux calculations. Hydrological processes, 17 (17), 3387, 2003.

23. ACHITE M., OUILLON S. Suspended sediment transport in a semiarid watershed, Wadi Abd, Algeria (1973-1995). Journal of hydrology, 343 (3), 187, 2007.

24. RODRÍGUEZ-BLANCO M., TABOADA-CASTRO M., TABOADA-CASTRO M. Factors controlling hydrosedimentary response during runoff events in a rural catchment in the humid Spanish zone. Catena, 82 (3), 206, 2010.

25. SADEGHI S.H.R., MIZUYAMA T., MIYATA S., GOMI T., KOSUGI K., FUKUSHIMA T., MIZUGAKI S. ONDA Y. Development, evaluation and interpretation of sediment rating curves for a Japanese small mountainous reforested watershed. Geoderma, 144 (1), 198, 2008.

26. ASSELMAN N. Fitting and interpretation of sediment rating curves. Journal of hydrology, 234 (3), 228, 2000.

27. CRAWFORD C.G. Estimation of suspended-sediment rating curves and mean suspended-sediment loads. Journal of hydrology, 129 (1-4), 331, 1991.

28. IADANZA C., NAPOLITANO F. Sediment transport time series in the Tiber River. Physics and Chemistry of the Earth, Parts A/B/C, 31 (18), 1212, 2006.

29. LOHANI A., GOEL N., BHATIA K.S. Deriving stagedischarge-sediment concentration relationships using fuzzy logic. Hydrological Sciences Journal, 52 (4), 793, 2007.

30. RUSTOMJI P., WILKINSON S. Applying bootstrap resampling to quantify uncertainty in fluvial suspended sediment loads estimated using rating curves. Water resources research, 44 (9), 2008.

31. WALLING D. Assessing the accuracy of suspended sediment rating curves for a small basin. Water resources research, 13 (3), 531, 1977.

32. FERGUSON R. River loads underestimated by rating curves. Water resources research, 22 (1), 74, 1986. 
33. KAO S.-J., LEE T.-Y., MILLIMAN J.D. Calculating highly fluctuated suspended sediment fluxes from mountainous rivers in Taiwan. Terrestrial Atmospheric and Oceanic Sciences, 16 (3), 653, 2005.

34. DUAN N. Smearing estimate: a nonparametric retransformation method. Journal of the American Statistical Association, 78 (383), 605, 1983.

35. ROVIRA A., BATALLA R.J. Temporal distribution of suspended sediment transport in a Mediterranean basin: The Lower Tordera (NE SPAIN). Geomorphology, 79 (1), 58,2006

36. RUZYCKI E.M., AXLER R.P., HOST G.E., HENNECK J.R., WILL N.R. Estimating sediment and nutrient loads in four western lake superior streams. JAWRA Journal of the American Water Resources Association, 50 (5), 1138, 2014.

37. DE GIROLAMO A., PAPPAGAllo G., PORTO A.L. Temporal variability of suspended sediment transport and rating curves in a Mediterranean river basin: The Celone (SE Italy). Catena, 128, 135, 2015.

38. HARRINGTON S.T., HARRINGTON J.R. An assessment of the suspended sediment rating curve approach for load estimation on the Rivers Bandon and Owenabue, Ireland. Geomorphology, 185, 27, 2013.

39. ISIK S. Regional rating curve models of suspended sediment transport for Turkey. Earth Science Informatics, 6 (2), 87, 2013.

40. MEYBECK M., MOATAR F. Daily variability of river concentrations and fluxes: indicators based on the segmentation of the rating curve. Hydrological processes, 26 (8), 1188, 2012.

41. COHN T., DELONG L., GILROY E., HIRSCH R., WELLS D. Estimating constituent loads. Water resources research, 25 (5), 937, 1989.

42. GIPPEL C.J., STEWARDSON M.J. Use of wetted perimeter in defining minimum environmental flows. Regulated rivers: research \& management, 14 (1), 53, 1998.

43. LIU S., MO X., XIA J. Uncertainty analysis in estimating the minimum ecological instream flow requirements via wetted perimeter method: curvature technique or slope technique. ACTA GEOGRAPHICA SINICA-CHINESE EDITION-, 61 (3), 281, 2006.

44. MOSLEMZADEH M., SALARIZAZI M., SOLEYMANI S. Application and assessment of kriging and cokriging methods on groundwater level estimation. J Am Sci, 7 (7), 34, 2011.

45. EIDIPOUR A., AKHONDALI A.M., ZAREI H., SALARIJAZI M. Flood Hydrograph Estimation Using GIUH Model in Ungauged Karst Basins (Case Study: Abolabbas Basin). TUEXENIA, 36 (36), 26, 2016.

46. SHAH R., SAHAI A.K., MISHRA V. Short to subseasonal hydrologic forecast to manage water and agricultural resources in India. Hydrology and Earth System Sciences, 21 (2), 707, 2017.

47. AZMAT M., LAIO F., POGGI D. Estimation of water resources availability and mini-hydro productivity in high-altitude scarcely-gauged watershed. Water Resources Management, 29 (14), 5037, 2015.

48. REZAEE PAZHAND H. Application of probability and statistics in water resources: Sokhan Gostar Press. 2001.

49. SALAZAR O., WESSTRÖM I., JOEL A. Evaluation of DRAINMOD using saturated hydraulic conductivity estimated by a pedotransfer function model. Agricultural water management, 95 (10), 1135, 2008.

50. KELLY C.N., MCGUIRE K.J., MINIAT C.F., VOSE J.M. Streamflow response to increasing precipitation extremes altered by forest management. Geophysical Research Letters, 43 (8), 3727, 2016.

51. WILLMOTT C.J., ACKLESON S.G., DAVIS R.E., FEDDEMA J.J., KLINK K.M., LEGATES D.R., O'DONNELL J., ROWE C.M. Statistics for the Evaluation and Comparison of Models. Journal of Geophysical Research. 90 (C5), 8995, 1985.

52. ADIB A., SALARIJAZI M., SHOOSHTARI M.M., AKHONDALI A.M. Comparison between characteristics of geomorphoclimatic instantaneous unit hydrograph be produced by GcIUH based Clark Model and Clark IUH model. Journal of Marine Science and Technology, 19 (2), 201, 2011. 